\title{
Age-dependent patterns of antioxidants in Arctica islandica from six regionally separate populations with different lifespans
}

\author{
Larisa Basova ${ }^{1, *}$, Salma Begum ${ }^{2}$, Julia Strahl ${ }^{3}$, Alexey Sukhotin ${ }^{4}$, Thomas Brey ${ }^{3}$ \\ Eva Philipp ${ }^{5}$, Doris Abele ${ }^{3}$ \\ ${ }^{1}$ St. Petersburg State University, Vasilievsky Island, 16 line, 29, 199178 St. Petersburg, Russia \\ ${ }^{2}$ Khulna University, Environmental Science Discipline, 9208 Khulna, Bangladesh \\ ${ }^{3}$ Alfred-Wegener Institute for Polar and Marine Research, Am Handelshafen 12, 27570 Bremerhaven, Germany \\ ${ }^{4}$ White Sea Biological Station, Zoological Institute of Russian Academy of Sciences, Universitetskaya nab., 1 , \\ 199034 St. Petersburg, Russia \\ ${ }^{5}$ Institute of Clinical Molecular Biology, Schittenhelmstrasse 12, 24105 Kiel, Germany
}

\begin{abstract}
Environmental factors such as temperature and salinity regimes shape lifespan in marine ectotherms. We investigated whether the effect occurs through modification of metabolic reactive oxygen species (ROS)-producing processes and is thus in line with the rate of living-free radical theory of aging. We compared 6 biogeographically and climatically distinct populations of the extremely long-lived ocean quahog Arctica islandica for age-dependent differences in metabolic rates and antioxidant capacities (superoxide dismutase, catalase activity and total glutathione concentration). The temperature and salinity ranges covered by the sampling locations (Norwegian coast, White Sea, Iceland, Kattegat, Kiel Bay and German Bight) were 3.7 to $9.3^{\circ} \mathrm{C}$ and 20 to 35 ppt. Bivalve shells were used as age recorders by counting annual growth bands. Maximum determined age in different populations varied between 29 and 192 yr. Extreme longevity observed in some North Atlantic A. islandica populations seems to be based on their very low lifetime mass-specific respiration, in combination with stable maintenance of antioxidant protection throughout life in mature specimens. While the antioxidant capacity was similar among all populations, the shorter-lived populations exhibited the highest metabolic rates and showed no metabolic response $\left(Q_{10}\right)$ when warmed to higher temperature. Low and fluctuating salinity in the Baltic may further exert stress, which enhances respiration rates and reduces longevity in the Baltic Sea population. The exceptionally long lifespan of $A$. islandica cannot be exclusively explained by a well-established antioxidant defense system, and the long lifespan of some populations may rather be a function of low ROS formation (low metabolic rate) and high damage repair/removal capacities.
\end{abstract}

KEY WORDS: Arctica islandica $\cdot$ Longevity $\cdot$ Antioxidants $\cdot$ Metabolic rate $\cdot$ Aging $\cdot$ Temperature $\cdot$ Salinity $\cdot$ Inter-population variability

Resale or republication not permitted without written consent of the publisher

\section{INTRODUCTION}

Some marine bivalves are extremely long-lived, and among non-colonial organisms, the ocean quahog Arctica islandica has the longest confirmed life- span (Ridgway \& Richardson 2011). One individual with a lifespan of more than $400 \mathrm{yr}$ has been reported (Wanamaker et al. 2008). According to the rate of living-free radical theory of aging (Pearl 1928, Harman 1956), mitochondrial reactive oxygen species 
(ROS) formation links cellular oxygen consumption to individual lifespan. The argument is that higher metabolic oxygen consumption causes higher basal ROS production and faster accumulation of peroxidized metabolic intermediates, thereby accelerating the loss of cellular function and viability and propelling cellular aging. ROS carry odd numbers of electrons in binding orbitals and are able to extract other electrons from lipids, causing lipid peroxidation, as well as oxidize proteins and DNA molecules. Although the basic idea of ROS involvement in aging has been acknowledged in numerous studies for different model organisms and cell cultures, the issues are not as straightforward as was previously assumed. Recent studies of genetically manipulated mice failed to provide evidence for a connection between ROS generation, antioxidant capacity and lifespan (Jang et al. 2009, Pérez et al. 2009). Further, some species or higher taxa do not follow the rules of the rate of living - free radical theory of aging, and especially, many marine invertebrates have lower life expectancy than would be predicted from their low metabolic rates (Buttemer et al. 2010).

Studies comparing species with similar lifestyles from different environments to explain the modulating effect of environmental factors on aging are susceptible to confounding effects of genetic peculiarities, especially in invertebrate groups with long evolutionary histories and large genetic distances between animals with similar appearances. Hence, for these investigations, single species with broad geographical distribution seem to be promising models. Bivalve mollusks are suitable for biogeographical aging research (Abele et al. 2009, Philipp \& Abele 2010). This group accommodates a high diversity of species-specific lifespans, and age determination of individuals can easily be done by counting annually forming growth bands in the bivalve shells (except for tropical species which usually do not feature annual growth rings). In previous studies of cellular and organism aging, we could see that the rate of living - free radical theory applies in principle, but different bivalve 'aging phenotypes' can be distinguished (Abele et al. 2009). Extremely long-lived and slow-growing species, such as the ocean quahog Arctica islandica, display high antioxidant capacities (mainly antioxidant enzyme activities and glutathione redox buffer concentrations) and efficient cellular waste removal is maintained at a constant level over an age range of at least 7 to $150 \mathrm{yr}$ (Strahl \& Abele 2010). In contrast, some short-lived bivalves have developed physiological and biochemical strategies that retard the aging process (Philipp et al.
2006) until reproductive capacities are exhausted. These species often feature high growth rates and, repeatedly, mobilize and reallocate energy reserves between somatic growth and reproduction. Further, ROS-producing and -scavenging capacities are modified by climatic adaptation of metabolic rates in ectotherms and are specifically adjusted in ectotherms from different latitudes (Abele \& Puntarulo 2004).

The aim of the present study was to compare biogeographically and climatically distinct populations of Arctica islandica that differ with respect to population-specific lifespan. The ocean quahog colonizes areas with diverse environmental conditions in the Northern Atlantic Ocean, along both European and American coasts, and genetic differences between populations are small (Dahlgren et al. 2000). Six geographically separated populations were included in our study. Determined individual maximum lifespan (MLSP) varies between 29 and $192 \mathrm{yr}$ across these populations (Begum et al. 2009), with especially old individuals encountered in an Icelandic population (Schöne et al. 2005a, Wanamaker et al. 2008). If antioxidants are indeed major factors supporting longevity, we should see far higher levels in populations with documented longer lifespans. Further, if declining antioxidant capacity over lifetime is a major cause of aging, $30 \mathrm{yr}$ old animals from the short-lived Baltic Sea population should have lower capacities than $100 \mathrm{yr}$ old, and thus in respect to the MLSP physiologically younger, specimens from the long-lived Icelandic or North Sea populations.

\section{MATERIALS AND METHODS}

\section{Animal and tissue sampling}

Arctica islandica were collected from 6 different geographic locations covering a temperature and salinity gradient of 3.7 to $9.3^{\circ} \mathrm{C}$ and 20 to $35 \mathrm{ppt}$, respectively: Norwegian Coast (NC), Kattegat (KA), White Sea (WS), Kiel Bay (KB), German Bight (GB), and Iceland (IC) (Table 1, Fig. 1). The animals were sampled mostly by trawling, and by trawling and diving in the WS. The months of collection are indicated by filled symbols for each population in Fig. 1. Animals were transported live to the Alfred-WegenerInstitute (AWI, Germany). Here they were kept for at least $1 \mathrm{wk}$ at a temperature close to mean annual habitat temperature (Table 1) and the salinity of the respective sampling site in $60 \mathrm{l}$ flow-through aquaria with natural seawater and sediment, to recover from 
Table 1. Characteristics of sampling sites, temperature conditions and age range of Arctica islandica used for respiration and antioxidant determination. (Depth: sampling depth, HT: acclimation habitat temperature, ET: $5^{\circ} \mathrm{C}$ elevated acclimation temperature). Mean annual temperature, salinity, and its amplitudes for each population around the depths where A. islandica lives were calculated from the ICES internet database www.ices.dk

\begin{tabular}{|c|c|c|c|c|c|c|c|c|c|c|}
\hline \multirow[t]{2}{*}{ Population } & \multirow[t]{2}{*}{ Location } & \multirow{2}{*}{$\begin{array}{l}\text { Depth, } \\
\text { m }\end{array}$} & \multicolumn{2}{|c|}{ Salinity } & \multicolumn{2}{|c|}{ Temperature } & \multirow{2}{*}{$\begin{array}{l}\mathrm{HT}, \\
{ }^{\circ} \mathrm{C}\end{array}$} & \multirow{2}{*}{$\begin{array}{l}\mathrm{ET}, \\
{ }^{\circ} \mathrm{C}\end{array}$} & \multirow{2}{*}{$\begin{array}{c}\text { Duration of } \\
\text { acclimation } \\
\text { to HT (ET), } \\
\text { mo }\end{array}$} & \multirow{2}{*}{$\begin{array}{c}\text { Age range } \\
\text { biochemistry } \\
\text { (respiration), } \\
\text { yr }\end{array}$} \\
\hline & & & $\begin{array}{c}\text { Annual } \\
\text { mean, } \\
\text { ppt }\end{array}$ & $\begin{array}{c}\text { Seasonal } \\
\text { amplitude, } \\
\text { ppt }\end{array}$ & $\begin{array}{l}\text { Annual } \\
\text { mean, } \\
{ }^{\circ} \mathrm{C}\end{array}$ & $\begin{array}{l}\text { Seasonal } \\
\text { amplitude, } \\
{ }^{\circ} \mathrm{C}\end{array}$ & & & & \\
\hline $\begin{array}{l}\text { Norwegian } \\
\text { Coast (NC) }\end{array}$ & $69^{\circ} 39 \mathrm{~N}, 18^{\circ} 57 \mathrm{E}$ & $10-30$ & 34 & 0.7 & 6.4 & 5.6 & 4 & 9 & $3-4(6-7)$ & $54-80(4-93)$ \\
\hline White Sea (WS) & $66^{\circ} 18 \mathrm{~N}, 33^{\circ} 38 \mathrm{E}$ & $10-15$ & 26 & 2.7 & 3.7 & 12.6 & 4 & 9 & $3-4(6)$ & $5-34(3-53)$ \\
\hline Iceland (IC) & $66^{\circ} 02 \mathrm{~N}, 14^{\circ} 51 \mathrm{~W}$ & $14-22$ & 35 & 0.4 & 4.1 & 6.2 & 5 & 10 & $1-4(5-6)$ & $5-192(8-141)$ \\
\hline Kattegat (KA) & $56^{\circ} 10 \mathrm{~N}, 11^{\circ} 48 \mathrm{E}$ & 33 & 32 & 2.5 & 8.0 & 6.7 & 8 & 13 & $5-6(9)$ & $15-39(8-71)$ \\
\hline Kiel Bay (KB) & $54^{\circ} 32 \mathrm{~N}, 10^{\circ} 42 \mathrm{E}$ & 25 & $20-25$ & 4.8 & 7.3 & 9.3 & 10 & 15 & $6-7(9-10)$ & $3-28(4-29)$ \\
\hline $\begin{array}{l}\text { German } \\
\text { Bight (GB) }\end{array}$ & $54^{\circ} 09 \mathrm{~N}, 07^{\circ} 47 \mathrm{E}$ & 40 & 33 & 1.1 & 9.3 & 11.6 & 10 & 15 & $1-2(1-2)$ & $34-125(33-98)$ \\
\hline
\end{tabular}

sampling and transportation stress. Bivalves were fed once a week with DT's Live Marine Plankton (DT, $1 \mathrm{ml}$ ind. $\left.^{-1} \mathrm{wk}^{-1}\right)$. Animals intended for respiration measurements remained in the aquaria for $4 \mathrm{wk}$ acclimation prior to experimental start. The other animals were dissected within days after the first week of acclimation, and pieces of mantle and foot tissues were snap frozen in liquid nitrogen for biochemical analysis.

\section{Whole animal metabolic rate}

Whole animal metabolic rates were measured as oxygen consumption at habitat temperatures (HT) and $5^{\circ} \mathrm{C}$ elevated temperature (ET) (Table 1) in a multi-channel modified intermittent flow system as

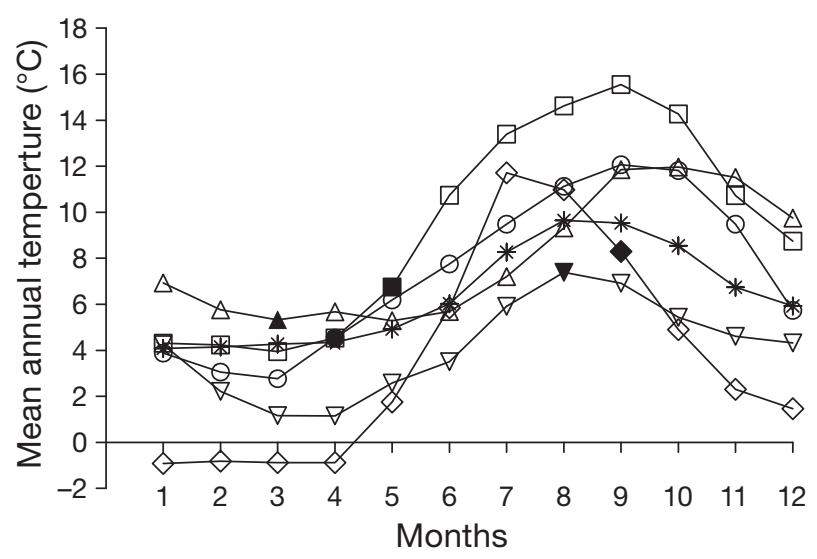

Fig. 1. Mean annual water temperature plot in sites of ArCtica islandica collection: Norwegian coast (*), White Sea $(\diamond)$, Iceland $(\nabla)$, Kattegat $(\bigcirc)$, Kiel Bay $(\Delta)$ and German Bight $(\square)$. Solid symbols indicate the sampling months; Norwegian coast samples were collected in April.. Data were calculated from the ICES internet database www.ices.dk described by Begum et al. (2009). The first subsample was maintained at HT for at least $4 \mathrm{wk}$, whereas the second subsample was acclimated stepwise $\left(1^{\circ} \mathrm{C}\right.$ temperature increase every 2 d) to ET. ET bivalves were kept for at least $4 \mathrm{wk}$ at the elevated temperature prior to respiration measurements. Prior to measurements, Arctica islandica were maintained without food for $3 \mathrm{~d}$, to eliminate the impact of specific dynamic action (SDA) on respiration (Bayne et al. 1976). Bivalves were allowed to acclimatize to the respiration chambers overnight, and oxygen consumption was recorded only in actively respiring animals that had their siphons open and extended into the surrounding water. Animals that did not respire, or that showed long periods of zero respiration, were discarded. Apneal respiration (AP) events, time limited intervals with zero oxygen consumption over 10 to $30 \mathrm{~min}$, were recorded (frequency and duration) and are included in the computation of overall respiration rate. Respiration rates $\left(R, \mu \mathrm{mol} \mathrm{O}_{2} \mathrm{~h}^{-1}\right.$ ind.- $\left.{ }^{-1}\right)$ were determined from the slope of the oxygen saturation curve after subtraction of the microbial oxygen demand (chamber without animal). Percent $\mathrm{O}_{2}$ saturation was transformed to $\mathrm{O}_{2}$ volume concentration using known values of oxygen solubility (Benson \& Krause 1984):

$$
R=-\frac{\left(\text { sat }_{\mathrm{o}}-\text { sat }_{1}\right)}{100 \cdot\left(\mathrm{t}_{\mathrm{o}}-\mathrm{t}_{1}\right)} \cdot \alpha_{\mathrm{O}_{2}} \cdot \mathrm{V}_{\text {chamber }}
$$

where $R$ is respiration rate $\left(\mu \mathrm{mol} \mathrm{O}_{2} \mathrm{~h}^{-1}\right.$ ind. $\left.^{-1}\right), \alpha_{\mathrm{O}_{2}}$ is oxygen solubility in seawater $\left(\mu \mathrm{mol} \mathrm{dm}{ }^{-3}\right), V_{\text {Chamber }}$ is the volume of the respiration chamber and tubing $\left(\mathrm{dm}^{3}\right), \mathrm{t}_{0}$ is the time (h) and sat $\mathrm{t}_{0}$ is oxygen saturation $(\%)$ at the beginning of experiment, $t_{1}$ is the time and sat $t_{1}$ is oxygen saturation (\%) after reduction of oxygen saturation to $70 \%$ of the initial value in the 
closed system.. Individual mass-specific respiration rates (MSR) were calculated according to:

$$
\operatorname{MSR}=\frac{R}{\mathrm{AFDM}}
$$

where MSR is the mass-specific respiration rate $\left(\mu \mathrm{mol} \mathrm{O} \mathrm{O}^{-1} \mathrm{~g}^{-1}\right), R$ is the respiration rate $\left(\mu \mathrm{mol} \mathrm{O}_{2}\right.$ $\mathrm{h}^{-1}$ ind. ${ }^{-1}$ ), and AFDM is the ash-free dry mass $(\mathrm{g})$.

MSR was standardized to the average mean size of mollusks in all populations $\left(\mathrm{AFDM}_{\mathrm{st}}=3.54 \mathrm{~g}\right)$ according to Eq. (3) using the three-quarters power law, in which the metabolic rate is proportional to the 0.75 power of the body mass, which means that the relationship $\ln$ MSR to $\ln$ AFDM has slope $b=-0.25$ (McMahon 1973):

$$
\mathrm{MSR}_{\mathrm{st}}=\mathrm{e}^{\ln \mathrm{MSR}_{\mathrm{obs}}+b\left(\ln \mathrm{AFDM}_{\mathrm{st}}-\ln \mathrm{AFDM}_{\mathrm{obs}}\right)}
$$

where $\mathrm{MSR}_{\mathrm{st}}$ is the mass-specific respiration rate for a standard size mollusk, $\mathrm{MSR}_{\mathrm{obs}}$ is the observed mass-specific respiration rate, and $\mathrm{AFDM}_{\mathrm{obs}}$ is the observed individual ash-free dry mass.

The effect of temperature on MSR was estimated, using the Arrhenius-Vant-Hoff's temperature coefficient $Q_{10}$. We chose animals of similar size and age from each population at 2 temperatures and calculated $\mathrm{MSR}_{\mathrm{st}}$ at 2 different temperatures i.e. habitat and $5^{\circ} \mathrm{C}$ elevated:

$$
Q_{10}=\left(\frac{\mathrm{MSR}_{\mathrm{st} \mathrm{ET}}}{\mathrm{MSR}_{\mathrm{st} \mathrm{HT}}}\right)^{\frac{10}{\mathrm{ET}-\mathrm{HT}}}
$$

where ET is the elevated temperature $\left({ }^{\circ} \mathrm{C}\right)$, HT is the habitat temperature $\left({ }^{\circ} \mathrm{C}\right), \mathrm{MSR}_{\mathrm{StET}}$ is the standard mass-specific respiration at elevated temperature, and $\mathrm{MSR}_{\mathrm{stHT}}$ is the standard mass-specific respiration at habitat temperature.

In order to compare MSR in different populations (Table 1), MSR values were recalculated for the 3 temperatures 4,9 and $14^{\circ} \mathrm{C}$ using the obtained $Q_{10}$ coefficients:

$$
\mathrm{MSR}_{\text {st } t_{2}}=\mathrm{e}^{\ln \mathrm{MSR}_{\mathrm{st} t_{1}}+Q_{10} \cdot\left(t_{2}-t_{1}\right) / 10}
$$

where $\mathrm{MSR}_{\mathrm{st} t_{2}}$ is the mass-specific respiration rate at standard temperature $\left(4,9\right.$ or $\left.14^{\circ} \mathrm{C}\right), \mathrm{MSR}_{\mathrm{st} t_{1}}$ is the mass-specific respiration rate at in situ temperature, $Q_{10}$ is the $Q_{10}$ calculated from Eq. (4), $t_{1}$ is the in situ temperature, and $t_{2}$ is the standard temperature.

\section{Measurements of antioxidant activity}

Superoxide dismutase (SOD, EC 1.15.1.1) activity was measured spectrophotometrically at $550 \mathrm{~nm}$ following Livingstone et al. (1992). Samples of 50 to
$100 \mathrm{mg}$ of foot tissue and 100 to $200 \mathrm{mg}$ of mantle tissue were ground in liquid nitrogen and homogenized in Tris buffer (20 mM Tris-HCl, $1 \mathrm{mM}$ EDTA, pH 7.6) at a ratio of 1:30 (w/v), using a glass homogenizer. Samples were centrifuged for $3 \mathrm{~min}$ at $12000 \times g$ at $4^{\circ} \mathrm{C}$. SOD activity is measured as degree of inhibition of the reduction of cytochrome $C$ by $\mathrm{O}_{2}^{--}$generated by a xanthine oxidase/xanthine system in $43 \mathrm{mM}$ potassium buffer with $0.1 \mathrm{mM}$ EDTA, pH 7.8, at $20^{\circ} \mathrm{C}$. One unit of SOD inhibits the reduction of cytochrome $c$ by $50 \%$ under the assay conditions. Mitochondrial and cytosolic SOD isoforms were not distinguished.

Catalase (Cat, EC 1.11.1.6) activity was determined following Aebi (1984). Samples of 50 to $100 \mathrm{mg}$ of foot tissue and 100 to $200 \mathrm{mg}$ of mantle tissue were each ground in liquid nitrogen and homogenized with a micropistill in $50 \mathrm{mM}$ phosphate buffer $(50 \mathrm{mM}$ $\mathrm{KH}_{2} \mathrm{PO}_{4}, 50 \mathrm{mM} \mathrm{Na} \mathrm{HPO}_{4}, \mathrm{pH}=7.0$ ) with 0.1 Triton $\mathrm{X}-100$ at a ratio of 1:6 (w/v). Samples were centrifuged at $12000 \times g$ for $15 \mathrm{~min}$ at $4^{\circ} \mathrm{C}$. The activity was determined by recording the time of $\mathrm{H}_{2} \mathrm{O}_{2}$ decomposition, resulting in a decrease of absorption from 0.45 to 0.40 at $240 \mathrm{~nm}$, at $20^{\circ} \mathrm{C}$.

Total glutathione concentration (tGSH; GSH+ 2GSSG) was measured following Griffith (1980) and Tietze (1969). Samples of 50 to $80 \mathrm{mg}$ for foot and 50 to $100 \mathrm{mg}$ for frozen mantle tissue were ground in liquid nitrogen and homogenized using a precooled glass homogenizer in ice-cold 5\% sulfosalycilic acid (previously bubbled with nitrogen gas) at a ratio of 1:10 (w/v). The homogenate was bubbled with $\mathrm{N}_{2}$ gas for $30 \mathrm{~s}$ and then centrifuged for $5 \mathrm{~min}$ at $15000 \times g$ at $4^{\circ} \mathrm{C}$. The sulfhydryl group of $\mathrm{GSH}$ reacts with DTNB (5,5'-dithiobis-(2-nitrobenzoic acid), Ellman's reagent) and produces a yellow-colored 5-thio-2-nitrobenzoic acid (TNB). Oxidized glutathione disulfide (GSSG) is reduced by NADPH in the presence of glutathione reductase. Assay conditions were: $0.3 \mathrm{mM}$ NADPH, $6 \mathrm{mM}$ DTNB and $50 \mathrm{U} \mathrm{ml}^{-1}$ glutathione reductase in $125 \mathrm{mM}$ potassium phosphate buffer containing $6 \mathrm{mM}$ EDTA ( $\mathrm{pH}$ 7.2). The rate of formation of TNB was measured at $412 \mathrm{~nm}$, and tGSH was quantified by reference to a standard curve.

Citrate synthase (CS, EC 4.1.3.7, key enzyme of the citric acid cycle) activity was measured following Sidell et al. (1987). Samples of 80 to $100 \mathrm{mg}$ of foot and mantle tissue were each ground in liquid nitrogen and homogenized with a glass homogenizer (Nalgene) in Tris- $\mathrm{HCl}$ buffer (20 mM Tris$\mathrm{HCl}, 1 \mathrm{mM}$ EDTA, $0.1 \%$ Tween $^{\circledR} 20, \mathrm{pH}$ 7.4) at a ratio of 1:8 (w/v). Homogenates were sonicated on 
ice for $15 \mathrm{~min}$ in a Branson Sonifier 450 (output control 8, Duty cycle $50 \%$ ), and centrifuged for 5 min at $7400 \times g$ and $0^{\circ} \mathrm{C}$. CS activity was measured by recording the absorbance increase of $5 \mathrm{mM}$ DTNB in $75 \mathrm{mM}$ Tris $\mathrm{HCl}(\mathrm{pH} 8.0), 0.4 \mathrm{mM}$ acetyl-CoA and $0.4 \mathrm{mM}$ oxaloacetate at $412 \mathrm{~nm}$. Activity was calculated using an extinction coefficient $\varepsilon_{412}$ of $13.61 \mathrm{mM}^{-1} \mathrm{~cm}^{-1}$. Enzyme activities were expressed in $\mathrm{U} \mathrm{g}^{-1}$ wet mass (WM), and glutathione concentration was calculated as $\mathrm{nmol} \mathrm{g}^{-1}$ WM. Total antioxidant capacity was calculated for each individual in all populations as the percentage of each antioxidant (CAT, SOD, tGSH) of the maximal capacity measured for this particular antioxidant in the whole survey.

\section{Individual age determination}

Individual age of each animal used in the respiration experiments and all biochemical measurements was determined by counting the shell growth bands as described by Begum et al. (2009).

\section{Statistics}

Mass-specific respiration rate, enzyme activity ( $\mathrm{U} \mathrm{g}^{-1} \mathrm{WM}$ CS, SOD, CAT) and tGSH (nmol g $\left.{ }^{-1} \mathrm{WM}\right)$ may be affected by age, tissue type and population.

The effect of age on the measured traits was tested by regression analyses. We tested for differences among populations using ANOVA (dependent variable versus population by tissue type) and post-hoc Tukey's HSD test after Levene's test for homogeneity of variances. If the Levene's test was significant, we used nonparametric Kruskal-Wallis ANOVA. Differences between tissues within one population were tested by the Mann-Whitney $U$-test.

Further, as an experimental control, we tested for the effects of sampling date (Fig. 1) and duration of acclimation (Table 1) on respiration rate and the effect of differing maintenance times under laboratory acclimation conditions on the antioxidant parameter levels. A full interaction analysis of covariance (ANCOVA) of $\log (\mathrm{MSR})$ versus $\log$ (body mass), 1/temperature $(T)$, population, month of sampling and month of measurement and a full factorial interaction ANCOVA model of normalized and Box-Cox-transformed antioxidant levels versus time between capture and sampling (death of the animal) and type of antioxidant was conducted.

\section{RESULTS}

Mollusks belonging to 6 populations were assigned to 2 climatic groups: 'cold adapted' (NC, IC, WS, acclimated to lower temperatures of 4 to $5^{\circ} \mathrm{C}$, Table 1) and 'warm adapted' (KA, KB, GB, acclimated to higher temperatures of 8 to $10^{\circ} \mathrm{C}$; Table 1 ).

\section{Effect of maintenance time after capture on respiration and antioxidant levels}

There were no statistically significant effects $(p>$ 0.05 ) of sampling date or measurement date on respiration rate (full interaction ANCOVA of $\log (\mathrm{MSR})$ versus $\log (\mathrm{AFDM}), 1 / T$, population, month of sampling and month of measurement). There were no significantly $(p>0.05)$ elevated antioxidant levels shortly after sampling (full factorial ANCOVA of antioxidant level [SOD, CAT, tGSH] versus time after capture).

\section{Metabolic rates}

Since the age composition of mollusk samples differed significantly between populations (see Table 1), the effect of age on MSR was tested for the whole sample batch. No significant age dependence of MSR was observed (regression analyses, $\mathrm{p}>0.05$ ). Among the cold-adapted Arctica islandica, bivalves from the NC had the highest MSR at both acclimation temperatures when compared to IC and WS bivalves (Fig. 2, white and gray bars), which had similar and lower MSR. Mollusks from the warm climatic group did not differ in MSR at the high temperature of $14^{\circ} \mathrm{C}$ (Fig. 2, black bars). At the intermediate acclimation temperature of $9^{\circ} \mathrm{C}$, the average MSR of mollusks from the GB $\left(2.4 \mu \mathrm{mol} \mathrm{O} \mathrm{O}_{2} \mathrm{~h}^{-1} \mathrm{~g}^{-1}\right.$ AFDM) was significantly lower than that of mollusks from the KA (6.3 $\mu \mathrm{mol} \mathrm{O}_{2} \mathrm{~h}^{-1} \mathrm{~g}^{-1}$ AFDM, Fig. 2). There was no statistically significant difference in mean MSR between $\mathrm{KA}$ and KB. The MSRs of the mollusks from the $\mathrm{KB}$ and KA populations were almost indifferent to warming, and the respiratory $Q_{10}$ was 1.1 at both sites (Fig. 3). Of all the populations, the KB and KA animals were most adapted to variable environmental conditions, not only, but primarily, with respect to temperature and salinity. The other 4 populations were significantly more responsive to high temperature acclimation. Mollusks from the IC and GB populations were highly temperature sensitive, their metabolic rates doubling in response to a thermal 


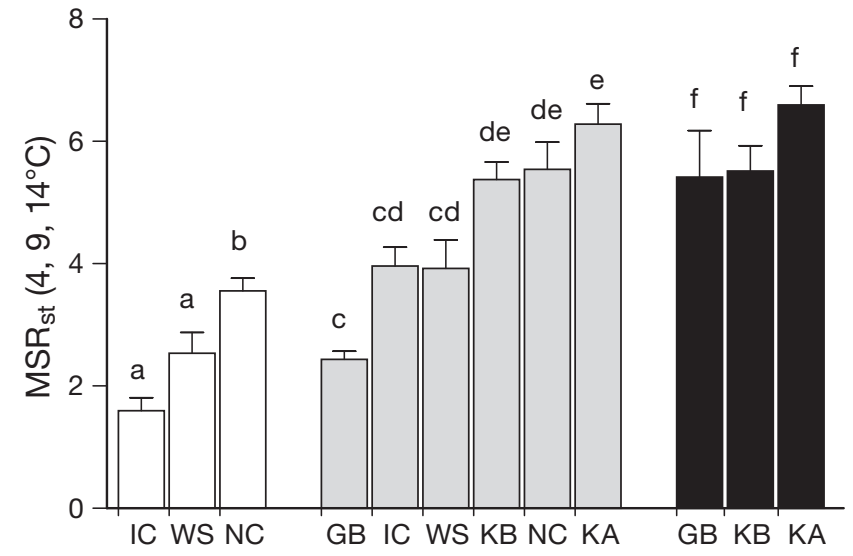

Fig. 2. Arctica islandica. Mass-specific respiration rate (MSR) standardized to mean mollusk size (3.54 g AFDM) at $4^{\circ}$ (white bars), $9^{\circ}$ (gray bars) and $14^{\circ} \mathrm{C}$ (black bars) in Iceland (IC), White Sea (WS), Norwegian coast (NC), German Bight (GB), Kiel Bay (KB) and Kattegat (KA) populations. Data are mean $\pm \mathrm{SE}$ expressed as $\mathrm{MSR}_{\mathrm{st}}\left(4,9,14^{\circ} \mathrm{C}\right), \mu \mathrm{mol} \mathrm{O}_{2} \mathrm{~h}^{-1} \mathrm{~g}^{-1}$ AFDM as average over lifetime. Significant differences between populations at each standard temperature (ANOVA,

$\mathrm{p}<0.05)$ are shown by different letters $(\mathrm{a}, \mathrm{b}, \mathrm{c}, \mathrm{d}, \mathrm{e}, \mathrm{f})$

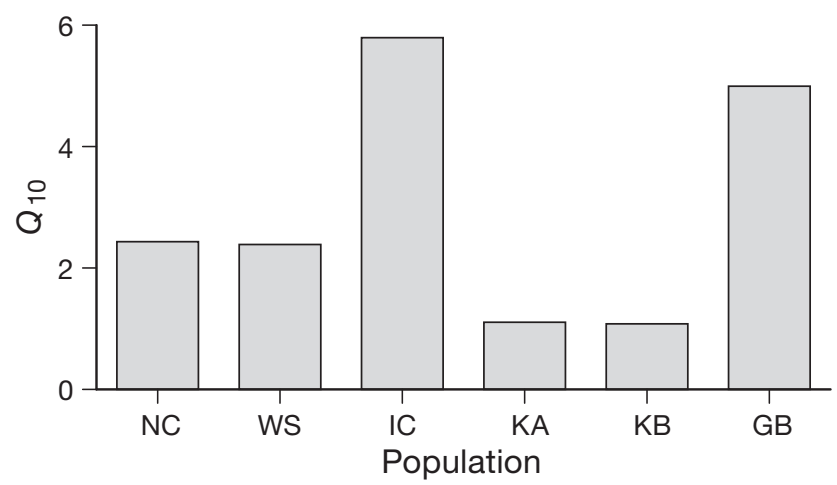

Fig. 3. Arctica islandica. $Q_{10}$ in Norwegian coast (NC), White Sea (WS), Iceland (IC), Kattegat (KA), Kiel Bay (KB) and German Bight (GB) populations the mollusks (individual antioxidant $\times$ population, Table 2). CS activity was only studied in animals from the GB where values remained stable over lifetime in foot and mantle, the only tissues we tested. The age influence on antioxidants differed between tissues. In mantle tissue, a negative correlation with age was observed for SOD activity in IC Arctica islandica and for CAT activity in GB and young immature IC animals. tGSH concentration decreased with age in immature IC animals (Table 2; data from the IC population were taken from Abele et al. 2008 and included in the regression analyses). In foot muscle, however, an age-related increase of SOD activity in bivalves from KB and the WS, and of CAT activity in KA bivalves, was observed (Table 2).

\section{Antioxidant capacities in different tissues}

The different components of the antioxidant system were distinctly weighted between Arctica islandica mantle and foot tissue (Table 3). Across populations, SOD activity and tGSH concentration were significantly higher in foot than in mantle tissue (Mann-Whitney U-test, p < 0.05, Fig. 4a,c, Table 3) (except tGSH concentration in the WS mollusks). In contrast, CAT activity was always significantly higher in mantle than in foot tissue (Mann-Whitney $U$-test, $\mathrm{p}<0.001$, Fig. 4b, Table 3). To check whether the higher SOD activity in foot tissue may relate to higher mitochondrial density, we exemplarily measured the activity of the mitochondrial marker citrate synthase (CS) in both tissues of the GB individuals. Indeed, CS activity was slightly higher in foot than in mantle tissue, (Mann-Whitney $U$-test, $\mathrm{p}=0.27$, Fig. 4d, Table 3). increment of $5^{\circ} \mathrm{C}\left(Q_{10}\right.$ values were 5.8 and 5.0, respectively, Fig. 3). A. islandica from the WS and NC increased their metabolic rate by 1.5 times at the elevated temperature $\left(Q_{10}=2.4\right.$, Fig. 3$)$ and appeared a little less sensitive to thermal challenge.

\section{Citrate synthase and antioxidant enzyme activities over age}

In the majority of populations, enzyme activities did not change with age of
Table 2. Arctica islandica. Relation between superoxide-dismutase (SOD), catalase (CAT), and citrate synthase (CS) activities and total glutathione concentration (tGSH) and age in different populations. (See Table 1 for full names.) Significance level: $\mathrm{p}<0.05 .+$ : positive correlation with age, - : negative correlation with age, no: no significant correlation; empty cells: no data

\begin{tabular}{|c|c|c|c|c|c|c|c|c|}
\hline \multirow{2}{*}{$\begin{array}{l}\text { Popu- } \\
\text { lation }\end{array}$} & \multicolumn{4}{|c|}{ Mantle } & \multicolumn{4}{|c|}{-Foot muscle- } \\
\hline & SOD & CAT & tGSH & CS & SOD & CAT & tGSH & CS \\
\hline $\mathrm{NC}$ & no & no & no & & no & no & no & \\
\hline WS & no & no & no & & + & no & no & \\
\hline IC & - & $\begin{array}{c}-(<33 \mathrm{yr}) \\
\text { no }(>33 \mathrm{yr})\end{array}$ & $\begin{array}{c}-(<33 \mathrm{yr}) \\
\text { no }(>33 \mathrm{yr})\end{array}$ & & & & & \\
\hline KA & no & no & no & & no & + & no & \\
\hline $\mathrm{KB}$ & no & no & no & & + & no & no & \\
\hline GB & no & - & no & no & no & no & no & no \\
\hline
\end{tabular}


Table 3. Arctica islandica. Activities of superoxide-dismutase (SOD), catalase (CAT) and citrate synthase (CS), total glutathione concentration (tGSH) and total antioxidant activity in foot and mantle tissues in different populations. (See Table 1 for full names.) Data are mean \pm SE expressed as $\mathrm{U} \mathrm{g}^{-1}$ wet mass (WM) as average over lifetime, except tGSH expressed as nmol $\mathrm{g}^{-1} \mathrm{WM}$ and total antioxidant activity expressed as \% of maximum antioxidant activity. $\mathrm{n}$ : number of individuals, -: no data

\begin{tabular}{|c|c|c|c|c|c|c|c|c|c|c|c|}
\hline Population & Tissue & SOD & $\mathrm{n}$ & CAT & $\mathrm{n}$ & tGSH & $\mathrm{n}$ & CS & $\mathrm{n}$ & Total antioxidants & $\mathrm{n}$ \\
\hline $\mathrm{NC}$ & Foot muscle & $2293.8 \pm 194.5$ & 10 & $598.8 \pm 40.0$ & 10 & $673.5 \pm 86.7$ & 10 & - & - & $59.3 \pm 3.3$ & 30 \\
\hline WS & & $1795.4 \pm 132.4$ & 19 & $505.8 \pm 29.5$ & 18 & $548.1 \pm 60.2$ & 7 & - & - & $50.0 \pm 2.2$ & 44 \\
\hline $\mathrm{KB}$ & & $1765.8 \pm 116.1$ & 17 & $683.5 \pm 38.0$ & 13 & $1055.9 \pm 88.8$ & 8 & - & - & $63.3 \pm 3.1$ & 38 \\
\hline GB & & $2184.8 \pm 112.7$ & 10 & $783.5 \pm 36.6$ & 10 & $701.3 \pm 44.1$ & 10 & $2.60 \pm 0.07$ & 8 & $65.2 \pm 2.9$ & 30 \\
\hline Mean & & $2034.4 \pm 71.2$ & 66 & $655.1 \pm 21.5$ & 61 & $749.2 \pm 39.2$ & 45 & - & - & $60.9 \pm 1.4$ & 172 \\
\hline WS & & $578.3 \pm 23.7$ & 24 & $2150.3 \pm 124.7$ & 28 & $404.9 \pm 63.2$ & 8 & - & - & $36.0 \pm 1.4$ & 60 \\
\hline IC & & $662.2 \pm 16.6$ & 37 & $3212.1 \pm 158.9$ & 41 & $419.3 \pm 40.2$ & 33 & - & - & $45.3 \pm 1.6$ & 111 \\
\hline KA & & $1137.7 \pm 59.1$ & 9 & $3094.1 \pm 250.0$ & 10 & $406.8 \pm 77.4$ & 10 & - & - & $53.6 \pm 4.0$ & 29 \\
\hline $\mathrm{KB}$ & & $863.0 \pm 69.0$ & 19 & $2543.3 \pm 168.9$ & 20 & $741.8 \pm 30.0$ & 15 & - & - & $55.1 \pm 2.8$ & 54 \\
\hline GB & & $866.7 \pm 74.7$ & 10 & $2618.3 \pm 261.5$ & 10 & $462.1 \pm 39.0$ & 10 & $2.22 \pm 0.27$ & 10 & $47.8 \pm 2.7$ & 30 \\
\hline Mean & & $781.0 \pm 26.4$ & 107 & $2780.4 \pm 86.0$ & 119 & $475.6 \pm 24.2$ & 86 & - & - & $47.1 \pm 1.0$ & 312 \\
\hline
\end{tabular}
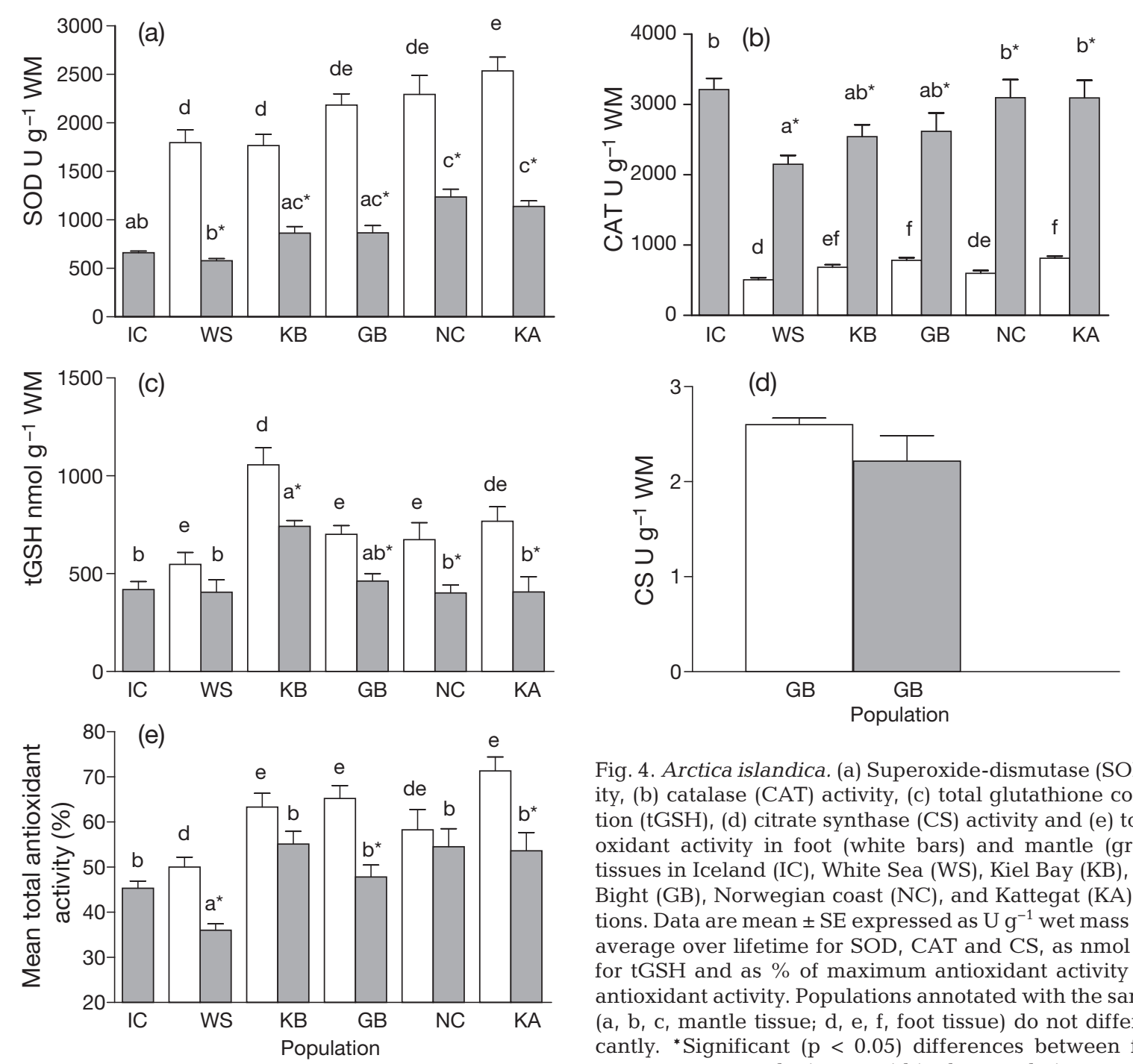

Fig. 4. Arctica islandica. (a) Superoxide-dismutase (SOD) activity, (b) catalase (CAT) activity, (c) total glutathione concentration (tGSH), (d) citrate synthase (CS) activity and (e) total antioxidant activity in foot (white bars) and mantle (gray bars) tissues in Iceland (IC), White Sea (WS), Kiel Bay (KB), German Bight (GB), Norwegian coast (NC), and Kattegat (KA) populations. Data are mean \pm SE expressed as $\mathrm{U} \mathrm{g}^{-1}$ wet mass (WM) as average over lifetime for SOD, CAT and CS, as nmol $\mathrm{g}^{-1} \mathrm{WM}$ for tGSH and as \% of maximum antioxidant activity for total antioxidant activity. Populations annotated with the same letter (a, b, c, mantle tissue; d, e, f, foot tissue) do not differ significantly. ${ }^{*}$ Significant $(\mathrm{p}<0.05)$ differences between foot and mantle tissues within the population 


\section{Antioxidant capacities in different populations}

SOD activity in both foot and mantle tissues were generally higher in KA, GB and NC bivalves (in fully saline habitats) than in KB and WS, where animals live in brackish water, although not all differences were statistically significant (Fig. 4a). The only exception was the fully marine, long-lived IC population (Abele et al. 2008), in which mean SOD activity was as low as in WS animals (only mantle tissue was measured and could be compared in IC animals).

Further, WS animals had the lowest CAT activity of all populations in both tissues. Similarly low CAT activity was recorded in NC foot muscle, whereas mantle tissue of NC specimens did not differ from the other populations and was higher than in WS animals (Fig. 4b). Arctica islandica from KB had higher tGSH concentrations in mantle and foot compared to all cold-adapted populations (IC, NC and WS). The cold-adapted populations had similar and lower tGSH concentrations in both tissues. Of all populations, the WS animals featured the lowest overall antioxidant capacity in mantle tissue and, together with NC animals, displayed the lowest antioxidant capacities in foot muscle (Fig. 4e).

\section{DISCUSSION}

\section{Can life-long high antioxidant protection explain extreme longevity of Arctica islandica?}

The exceptionally long lifespan of the bivalve Arctica islandica cannot be sufficiently explained by a better-established antioxidant defense system. Indeed, individual enzyme activities and tGSH range among, but not above, the highest values observed in mantle and foot tissues in other bivalves with shorter lifespan, such as Crassostrea virginica, Mya arenaria, Laternula elliptica, Adamussium colbecki, Mytilus edulis, Pecten jacobaeus and $P$. maximus (Ballantyne \& Berges 1991, Viarengo et al. 1991, 1995, Gamble et al. 1995, Sukhotin et al. 2002, Philipp et al. 2005a,b, 2006, Abele et al. 2008). However, in the presence of the same amount of antioxidants, ROS production by A. islandica mitochondria may be lower, either because of its extremely low metabolic rate (Begum et al. 2009), or because of more efficient mitochondrial electron transport in its mitochondria. Indeed, a recent compilation of in vitro ROS formation in mitochondrial isolates from different bivalve species indicated that $A$. islandica produces less mitochondrial ROS per mg of mitochondrial protein than other mud clams (Mya arenaria, Laternula elliptica) in respiratory states 3 and 4 under in vitro conditions (Buttemer et al. 2010). Thus, a well-established antioxidant defense, together with low species-specific metabolic rates and low basal mitochondrial ROS formation pose a strong argument for extended longevity of $A$. islandica.

An age effect on the metabolic rate of Arctica islandica was not observed in our study. A general decrease in mass-specific metabolic rate in the course of ageing has been reported for homeotherms and insects (for review see McCarter 1995); however, with a few exceptions (O'Connor et al. 2002). Especially for species with infinite growth, such as bivalves, it is difficult to distinguish between the effects of size and age, which are strongly correlated factors. Studies of mere age effects on metabolic rates in these species are quite rare, and the results are controversial. A decrease in respiration rate with age has been reported for the fish Cichlasoma nigrofasciatum (Fidhiany \& Winckler 1998) and for the bivalves Crenomytilus grayanus (Zolotarev \& Ryabushko 1977), Argopecten irradians irradians (Bricelj et al. 1987) and Mytilus edulis (Sukhotin \& Pörtner 2001, Sukhotin et al. 2006). However, in other studies this effect was weak or absent (Pérez Camacho et al. 2000, Sukhotin et al. 2002). In the present study, the age-dependent effect might however be obscured by the combination of the low metabolic rate, high inter-individual variability and the relatively low amount of data at older ages where such an effect would most likely be visible and also be more or less size independent.

A decline in antioxidant defense (catalase, glutathione) in aged animals is commonly related to advanced aging and has been detected in bivalve mollusks such as oysters (Ivanina et al. 2008), clams and scallops (Philipp et al. 2005a, 2006, 2008). Shorter-lived species (Aequipecten opercularis and Mya arenaria) display a faster increase in oxidative damage marker concentrations, together with a decrease in antioxidants with age when compared to longer-lived bivalves of similar lifestyle (Antarctic species Adamussium colbecki and Laternula elliptica, Philipp et al. 2005a,b, 2006). We found an agerelated decline in SOD activity in mantle tissue of Arctica islandica from the long-lived IC population, a decline in CAT activity (in young, not yet mature IC and GB mollusks), and a decline in tGSH concentration in immature IC mollusks ( $<32$ yr of age). In sexually mature IC animals ( $>30 \mathrm{yr}$ ), tGSH and CAT values did not change up to 150-190 yr of age (Table 2, Abele et al. 2008). The allometric decline in 
specific metabolic rate with increasing size within the phase of active growth, observed in A. islandica as in other mollusks, is supposedly tantamount to a reduction in free radical generation by the mitochondria, due to the decrease in metabolic rate with increasing size. This may reduce the need for energetically costly production of antioxidant enzymes in larger specimens, as observed in mantle tissue of A. islandica from some populations.

SOD activity increased in the foot tissue of $\mathrm{KB}$ and WS populations and CAT activity in KA bivalves also increased with age (Table 2). This upward trend of antioxidants with age is rarely observed in ectotherms. SOD and glutathione peroxidase increased with age in the shrimp Aristeus antennatus (Mourente \& Diaz-Salvago 1999), and glutathione concentration was higher in older than in younger Oncorhynchus mykiss (Passi et al. 2004). This trend may indicate the increased demand for antioxidants at advanced age but could also be an effect of sampling the 'late survivors'. These especially long-lived individuals within a population are presumed to be endowed with above average SOD or CAT activities from the beginning, and thus better protected from oxidative stress than their average congeners. As the relative abundance of these well protected 'late survivors' increases within older cohorts, antioxidants seemingly increase over age in a population. However, KA and WS populations also feature the shortest MLSP (Table 1) and experience the most intense environmental variability and the lowest habitat salinity. Thus, increasing antioxidants over population lifetime may indeed indicate physiological adjustments to elevated environmental stress in these populations. Nevertheless, within the age ranges studied in all 6 populations, we never detected a significant age influence on metabolic rate (MSR), or a consistent effect of age on antioxidant activities within one tissue across all populations (Table 2). We therefore conjecture that Arctica islandica are able to maintain low and stable MSR and mitochondrial ROS production over most of their lifetime and, at the same time, preserve constant levels of antioxidants into late age, but probably do not induce the levels in aged specimens. A. islandica do indeed have low mobility, low metabolic rates and avoid excessive tissue oxygenation by keeping $\mathrm{pO}_{2}$ in their mantle cavity fluid far below saturation level (Abele et al. 2010). Frequent events of self-induced metabolic rate depression of $A$. islandica (Taylor 1976), which were not included in our MSR results, are bound to significantly reduce even these very low measurable oxygen consumption and ROS production rates over lifetime under in situ con- ditions. Together, all these factors support the exceptionally long lifespan of the ocean quahog.

\section{Tissue specific antioxidant patterns}

The antioxidants are distinctly weighted in Arctica islandica mantle and foot tissues: 2-times higher SOD activity and tGSH concentrations in foot than in mantle contrast with 4-times higher CAT activity in mantle than foot tissue. Mantle is a respiratory tissue in bivalves, and the higher CAT activity may be targeted to the higher $\mathrm{O}_{2}$ concentrations in the mantle and detoxify ROS in actively respiring animals. In an earlier study investigating only the IC population, we observed even higher SOD and CAT activities and tGSH concentration in A. islandica gills than in mantle tissue (Abele et al. 2008). This is in keeping with the extension of the gills into the surrounding seawater in ventilating animals, whereas the mantle, although a respiratory surface, is located within the bivalve shell and mostly bathed in poorly oxygenated mantle cavity water (Abele et al. 2010). In contrast, the foot is a massive organ with relatively low surface area, either contracted into the shell, or extended into the sediment for burrowing movements and, thus, better protected from contact with oxygenated water. Foot muscle mitochondria may produce more $\mathrm{O}_{2}^{--}$during burrowing exercise. This $\mathrm{O}_{2}^{--}$is converted to $\mathrm{H}_{2} \mathrm{O}_{2}$ by SOD and further detoxified by CAT and the glutathione system. High antioxidant activities and glutathione levels are common in exercising muscle and glutathione levels in human skeletal muscle increase during exercise training (Powers et al. 1999).

\section{Among-population comparison}

MLSP in natural populations is often underestimated because its determination depends largely on contingency with respect to the chance of sampling the 'oldest' individuals in a population (Philipp \& Abele 2010). Therefore, reported MLSPs in wild populations should always be viewed with caution (Beukema 1988). However, the MLSP of Arctica islandica clearly differs between geographically separated populations. In the present study, the oldest specimens of 150 to $190 \mathrm{yr}$ were exclusively from the IC population, which is in agreement with reports of extremely old animals occurring in this region (Schöne et al. 2005b, Wanamaker et al. 2008). Next, the animals from the GB population are relatively 
long-lived, and the oldest animal we encountered was 125 yr old. The WS (<55 yr) and KB (<30 yr) populations had the shortest lifespans in our study, and animals of older age have never been reported from either area. A. islandica from IC and GB populations displayed the lowest MSR of all populations (Fig. 2) in spite of adaptation to different mean habitat temperature: cold in IC and warm-temperate in the GB, and different, although overlapping, annual temperature windows (Table 1). Narrower thermal windows and limited food supply during winter at higher latitudes have been suggested to reduce metabolic rates and favor burrowing and metabolic rate depression during winter (Buick \& Ivany 2004, Strahl \& Abele 2010), which might support extreme longevity at IC.

Hypothetically, thermal sensitivity of metabolism may also change with age in Arctica islandica. Thus, the observed inter-population differences might be explained by the age composition of the samples, i.e. IC and GB populations are represented by older animals than KB and KA populations. Higher respiratory $Q_{10}$ in the long-lived IC and warm-adapted GB populations, together with their low temperature-specific respiration rates at $4^{\circ} \mathrm{C}(\mathrm{IC})$ and $9^{\circ} \mathrm{C}(\mathrm{GB})$ are indicative of their high thermal sensitivity. By comparison, shorter-lived A. islandica from KB and KA were characterized by very low temperature dependence reflected by $Q_{10}$ values. This may be due to the fact that the animals were already warmed beyond maximum habitat temperatures and thus were not responding to the thermal increase. However, there was no sign of stress in these groups, such as accelerated death rates, so we assume that thermal stress was still minimal. Alternatively, higher basal MSRs in the population most strongly exposed to environmental fluctuations with respect to salinity and temperature (KB, KA and WS) imply a more flexible response to thermal challenge (see also Clarke \& Fraser 2004), shifts in protein expression and more adjustable mitochondrial energetic coupling (Keller et al. 2004). A new finding in our study is that this flexibility is acquired at the expense of population lifespan. In other words: wider thermal and salinity windows in KA, WS and KB reduce population life expectancy, as shown in Fig. 5. This causes $A$. islandica to adopt a new life strategy in 'low and variable salinity environments', in which more intense and perhaps earlier reproduction as well as adjustment of cellular metabolism and, presumably, protein expression in response to constantly changing environmental conditions enhances MSR and shortens lifespan. This is certainly not a genetic trait, but a slowly evolved phenotypic adjustment in response to more challenging/costly environmental conditions.

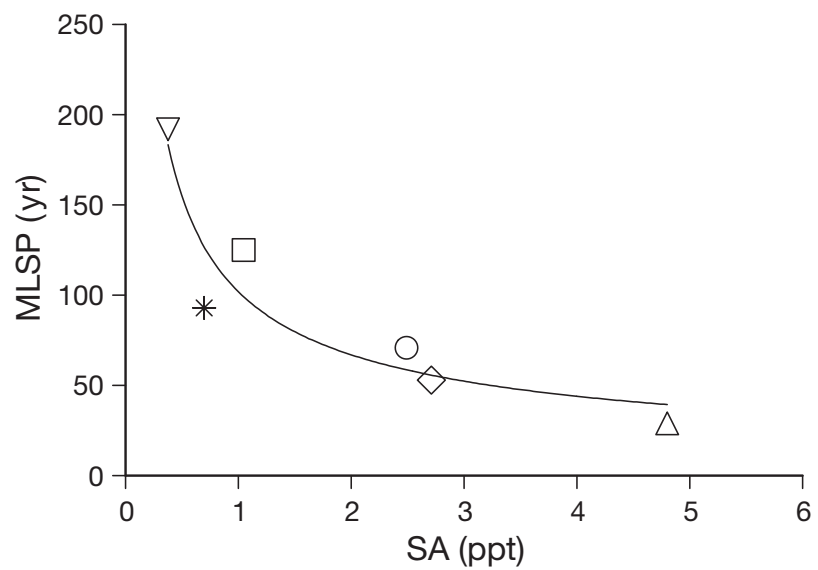

Fig. 5. Arctica islandica. Population-specific maximal lifespan (MLSP, yr) versus salinity amplitude (SA, ppt) in (*) Norwegian coast, $(\diamond)$ White Sea, $(\nabla)$ Iceland, $(O)$ Kattegat, $(\Delta)$ Kiel Bay and $(\square)$ German Bight populations. Best-fit line indicates regression of MLSP on salinity amplitude (MLSP = 102.1 $\mathrm{SA}^{-0.606}, \mathrm{n}=6, \mathrm{p}=0.0063$ )

The high thermal sensitivity retained in the GB Arctica islandica population may be posing a problem. The population is currently experiencing a widening of the annual temperature range between summer and winter extremes and a conspicuous warming trend (Wiltshire \& Manly 2004) connected to the global climate change, and is further suffering additional impact from fishery and eutrophication (Rijnsdorp \& van Leeuwen 1996, Rumohr \& Kujawski 2000). As a consequence, longevity is shorter than in the IC region, and young recruits of $<30$ yr are absent in the GB.

Antioxidant activities in different populations of Arctica islandica are much more homogenous than expected from their vastly differing MLSPs. In particular, the total antioxidant capacities are similar in most cases and only slightly lower in WS specimens (Fig. 4e). This intra-specific study of $A$. islandica populations clearly documents that antioxidant levels do not correlate with lifespan, and hence, these major ROS scavengers presumably support, but do not cause extreme longevity in the IC population. Instead, total antioxidant capacity, and CAT and SOD activities align with the mean annual habitat temperature recorded in each population habitat (see Tables 1 \& 3). This emphasizes that metabolic ROS formation increases at higher temperatures, and that ectotherms have to enhance levels of antioxidants and presumably other stress proteins to counteract thermal increases in ROS levels. Thus, enhanced antioxidants in warmer populations of the biogeographic distribution gradient balance oxidative stress, but do not increase life expectancy. This indicates 
that these organisms adjust their life history strategy to the environmental specifications, and express only so many antioxidants/stress proteins as required under these conditions. We conclude that population-specific MLSP in long-lived, relatively inactive and sessile marine ectotherms is subject to environmental forcing.

Acknowledgements. The authors thank the crews of the AWI and IfM-Geomar research vessels for dredging animals from the German Bight and Baltic Sea, L. Camus (AkvaplanNiva AS/University of Tromsø, Norway) for kindly providing animals from Norway and M. Sejr (National Environmental Research Institute, Denmark) for animals from Kattegat. Colleagues from the White Sea Biological Station (Kandalaksha Bay, Kartesh Cape) greatly supported this study by helping L.B. with dredging and scuba diving for collection of White Sea Arctica islandica. The study was funded by DAAD grants A/05/56588 and A/07/72522, and BMBF International Office RUS-07/A11 to L.B., and DAAD-Helmholtz fellowship grant A/05/22368 to S.B., as well as by the German Science foundation (DFG) project Ab124/10-1. While working on the manuscript, A.S. was supported by the Russian Foundation for Basic Research grant 10-04-00316 and by a fellowship of the Hanse Wissenschaftskolleg (Delmenhorst, Germany) and E.P. by the DFG Cluster of Excellence 'The Future Ocean'.

\section{LITERATURE CITED}

Abele D, Puntarulo S (2004) Formation of reactive species and induction of antioxidant defense systems in polar and temperate marine invertebrates and fish. Comp Biochem Physiol 138A:405-415

> Abele D, Strahl J, Brey T, Philipp E (2008) Imperceptible senescence: aging in the ocean quahog Arctica islandica. Free Radic Res 42:474-480

> Abele D, Brey T, Philipp E (2009) Bivalve models of aging and the determination of molluscan lifespans. Exp Gerontol 44:307-315

Abele D, Kruppe M, Philipp EER, Brey T (2010) Mantle cavity water oxygen partial pressure $\left(\mathrm{PO}_{2}\right)$ in marine molluscs aligns with lifestyle. Can J Fish Aquat Sci 67: 977-986

Aebi H (1984) Catalase in vitro. Methods Enzymol 105: 121-126

Ballantyne J, Berges JA (1991) Enzyme activities of gill, hepatopancreas, mantle, and adductor muscle of the oyster (Crassostrea virginica) after changes in diet and salinity. Can J Fish Aquat Sci 48:1117-1123

Bayne BL, Thompson RJ, Widdows J (1976) Physiology I. Marine mussels. Their ecology and physiology. Cambridge University Press, Cambridge, p 121-206

Begum S, Basova L, Strahl J, Sukhotin A and others (2009) A metabolic model for the ocean quahog Arctica islandica - effects of animal mass and age, temperature, salinity and geography on respiration rate. J Shellfish Res 28:533-539

Benson BB, Krause D Jr. (1984) The concentration and isotopic fractionation of oxygen dissolved in freshwater and seawater in equilibrium with the atmosphere. Limnol Oceanogr 29:620-632
Beukema JJ (1988) Bias in estimates of maximum life span, with an example of the edible cockle Cerastoderma edule. Neth J Zool 39:79-85

Bricelj VM, Epp J, Malouf RE (1987) Comparative physiology of young and old cohorts of bay scallop Argopecten irradians irradians (Lamarck): mortality, growth and oxygen consumption. J Exp Mar Biol Ecol 112:73-91

Buick DP, Ivany LC (2004) 100 years in the dark: extreme longevity of Eocene bivalves in Antarctica. Geology 32:921-924

Buttemer WA, Abele D, Costantini D (2010) From bivalves to birds: oxidative stress and longevity. Funct Ecol 24: 971-983

Clarke A, Fraser KPP (2004) Why does metabolism scale with temperature? Funct Ecol 18:243-251

Dahlgren TG, Weinberg JR, Halanych KM (2000) Phylogeography of the ocean quahog (Arctica islandica): influences of paleoclimate on genetic diversity and species range. Mar Biol 137:487-495

Fidhiany L, Winckler K (1998) Influence of body mass, age, and maturation on specific oxygen consumption in a freshwater cichlid fish, Cichlasoma nigrofasciatum (Guenther, 1869). Comp Biochem Physiol A 119:613-619

Gamble SC, Goldarb PS, Porte C, Livingstone DR (1995) Glutathione peroxidise and other antioxidant enzyme function in marine invertebrates (Mytilus edulis, Pecten maximus, Carcinus maenas and Asterias rubens). Mar Environ Res 39:191-195

Griffith OW (1980) Determination of glutathione and glutathione disulfide using glutathione reductase and 2vinylpyridine. Anal Biochem 106:207-212

Harman D (1956) Aging: a theory based on free radical and radiation biology. J Gerontol 11:298-300

Ivanina AV, Sokolova IM, Sukhotin AA (2008) Oxidative stress and expression of chaperones in aging mollusks. Comp Biochem Physiol B 150:53-61

> Jang YC, Perez VI, Song W, Lustgarten MS and others (2009) Overexpression of Mn superoxide dismutase does not increase life span in mice. J Gerontol A Biol Sci Med Sci 64A:1114-1125

Keller M, Sommer AM, Pörtner HO, Abele D (2004) Seasonality of energetic functioning and production of reactive oxygen species by lugworm (Arenicola marina) mitochondria exposed to acute temperature changes. J Exp Biol 207:2529-2538

> Livingstone DR, Lips F, Garcia Martinez P, Pipe RK (1992) Antioxidant enzymes in the digestive gland of the common mussel Mytilus edulis. Mar Biol 112:265-276

McCarter RJM (1995) Energy utilization. In: Masoro EJ (ed) Handbook of physiology, Section 11, Aging. Oxford University Press, New York, NY, p 95-118

McMahon T (1973) Size and shape in biology: Elastic criteria impose limits on biological proportions, and consequently on metabolic rates. Science 179:1201-1204

Mourente G, Diaz-Salvago E (1999) Characterisation of antioxidant systems, oxidation status and lipids in brain of wild-caught size-class distributed Aristeus antennatus (Risso, 1816) Crustacea, Decapoda. Comp Biochem Physiol 124B:405-416

O'Connor TP, Lee A, Jarvis JUM, Buffenstein R (2002) Prolonged longevity in naked mole-rats: age-related changes in metabolism, body composition and gastrointestinal function. Comp Biochem Physiol A 133:835-842

Passi S, Ricci R, Cataudella S, Ferrante I, De Simone F, Rastrelli L (2004) Fatty acid pattern, oxidation product devel- 
opment, and antioxidant loss in muscle tissue of rainbow trout and Dicentrarchus labrax during growth. J Agric Food Chem 52:2587-2592

Pearl R (1928) The rate of living. Alfred Knopf, New York

> Pérez VI, Bokov A, Remmen HV, Mele J, Ran Q, Ikeno Y, Richardson A (2009) Is the oxidative stress theory of aging dead? Biochim Biophys Acta 1790:1005-1014

Pérez Camacho A, Labarta U, Navarro E (2000) Energy balance of mussels Mytilus galloprovincialis: the effect of length and age. Mar Ecol Prog Ser 199:149-158

Philipp EER, Abele D (2010) Masters of longevity: lessons from long-lived bivalves - a mini-review. Gerontology 56:55-65

Philipp E, Brey T, Pörtner HO, Abele D (2005a) Chronological and physiological aging in a polar and a temperate mud clam. Mech Ageing Dev 126:589-609

Philipp E, Pörtner HO, Abele D (2005b) Mitochondrial aging in a polar and a temperate mud clam. Mech Ageing Dev 126:610-619

> Philipp E, Brey T, Heilmayer O, Abele D, Pörtner HO (2006) Physiological aging in a polar and a temperate swimming scallop. Mar Ecol Prog Ser 307:187-198

Philipp EER, Schmidt M, Gsottbauer C, Saenger AM, Abele D (2008) Size- and age-dependent changes in adductor muscle swimming physiology of the scallop Aequipecten opercularis. J Exp Biol 211:2492-2501

Powers SK, Ji LL, Leeuwenburgh C (1999) Exercise traininginduced alterations in skeletal muscle antioxidant capacity: a brief review. Med Sci Sports Exerc 31:987-997

Ridgway ID, Richardson CA (2011) Arctica islandica: the longest lived non colonial animal known to science. Rev Fish Biol Fish 21:297-310

Rijnsdorp AD, van Leeuwen PI (1996) Changes in growth of North Sea plaice since 1951 in relation to density, eutrophication, beam-trawl effort, and temperature. ICES J Mar Sci 53:1199-1213

Rumohr H, Kujawski T (2000) The impact of trawl fishery on the epifauna of southern North Sea. ICES J Mar Sci 57: 1389-1394

Schöne BR, Dunca E, Fiebig J, Pfeiffer M (2005a). Mutvei's solution: an ideal agent for resolving microgrowth structures of biogenic carbonates. Palaeogeogr Palaeoclimatol Palaeoecol 228:149-166

Schöne BR, Fiebig J, Pfeiffer M, Gleß R and others (2005b) Climate records from a bivalve Methuselah (Arctica

Editorial responsibility: Peter Beninger, Nantes, France islandica, Molluska; Iceland). Palaeogeogr Palaeoclimatol Palaeoecol 228:130-148

Sidell BD, Driedzic WR, Stowe DB, Johnston IA (1987) Biochemical correlations of power development and metabolic fuel preferenda in fish hearts. Physiol Zool 60: 221-232

> Strahl J, Abele D (2010) Cell turnover in tissues of the longlived ocean quahog Arctica islandica and the short-lived scallop Aequipecten opercularis. Mar Biol 157:1283-1292

Sukhotin AA, Pörtner HO (2001) Age-dependence of metabolism in mussels Mytilus edulis L. from the White Sea. J Exp Mar Biol Ecol 257:53-72

Sukhotin AA, Abele D, Pörtner HO (2002) Growth, metabolism and lipid peroxidation in Mytilus edulis: age and size effects. Mar Ecol Prog Ser 226:223-234

Sukhotin AA, Abele D, Pörtner HO (2006) Ageing and metabolism of Mytilus edulis: populations from various climate regimes. J Shellfish Res 25:893-899

- Taylor AC (1976) Burrowing behaviour and anaerobiosis in the bivalve Arctica islandica (L.). J Mar Biol Assoc UK 56:95-109

- Tietze F (1969) Enzymic method for quantitative determination of nanogram amounts of total and oxidized glutathione. Anal Biochem 27:502-522

> Viarengo A, Canesi L, Pertica M, Livingstone DR, Orunesu M (1991) Age-related lipid peroxidation in the digestive gland of mussels: the role of antioxidant defense systems. Experientia 47:454-457

Viarengo A, Canesi L, Garcha-Marthenez P, Peters LD, Livingstone DR (1995) Pro-oxidant processes and antioxidant defense systems in the tissues of the Antarctic scallop (Adamussium colbecki) compared with the Mediterranean scallop (Pecten jacobaeus). Comp Biochem Physiol B 111:119-126

Wanamaker AD, Heinemeier J, Scourse JD, Richardson C, Butler P, Eiriksson J, Knudsen K (2008) Very long-lived mollusks confirm 17th century AD tephra-based radiocarbon reservoir ages for north Icelandic shelf waters. Radiocarbon 50:399-412

Wiltshire KH, Manly BFJ (2004) The warming trend at Helgoland Roads, North Sea: phytoplankton response. Helgol Mar Res 58:269-273

Zolotarev VN, Ryabushko VI (1977) Age changes of energy metabolism in Crenomytilus grayanus Dunker. Z Obs Biol 38:923-928 (in Russian)

Submitted: November 5, 2010; Accepted: October 21, 2011 Proofs received from author(s): December 27, 2011 